\title{
The acute management of trauma hemorrhage: a systematic review of randomized controlled trials
}

\author{
Nicola Curry ${ }^{1 *}$, Sally Hopewell ${ }^{2,3}$, Carolyn Dorée ${ }^{2}$, Chris Hyde ${ }^{4}$, Karim Brohi ${ }^{5}$, Simon Stanworth ${ }^{1}$
}

\begin{abstract}
Introduction: Worldwide, trauma is a leading cause of death and disability. Haemorrhage is responsible for up to $40 \%$ of trauma deaths. Recent strategies to improve mortality rates have focused on optimal methods of early hemorrhage control and correction of coagulopathy. We undertook a systematic review of randomized controlled trials (RCT) which evaluated trauma patients with hemorrhagic shock within the first 24 hours of injury and appraised how the interventions affected three outcomes: bleeding and/or transfusion requirements; correction of trauma induced coagulopathy and mortality.
\end{abstract}

Methods: Comprehensive searches were performed of MEDLINE, EMBASE, CENTRAL (The Cochrane Library Issue 7 , 2010), Current Controlled Trials, ClinicalTrials.gov, the World Health Organization International Clinical Trials Registry Platform (ICTRP) and the National Health Service Blood and Transplant Systematic Review Initiative (NHSBT SRI) RCT Handsearch Database.

Results: A total of 35 RCTs were identified which evaluated a wide range of clinical interventions in trauma hemorrhage. Many of the included studies were of low methodological quality and participant numbers were small. Bleeding outcomes were reported in 32 studies; 7 reported significantly reduced transfusion use following a variety of clinical interventions, but this was not accompanied by improved survival. Minimal information was found on traumatic coagulopathy across the identified RCTs. Overall survival was improved in only three RCTs: two small studies and a large study evaluating the use of tranexamic acid.

Conclusions: Despite 35 RCTs there has been little improvement in outcomes over the last few decades. No clear correlation has been demonstrated between transfusion requirements and mortality. The global trauma community should consider a coordinated and strategic approach to conduct well designed studies with pragmatic endpoints.

\section{Introduction}

Trauma is one of the world's leading causes of death and disability. Around $40 \%$ of deaths are due to bleeding or its consequences, establishing hemorrhage as the most common cause of preventable death in this clinical group [1-3]. The relationship between trauma hemorrhage and poor outcomes has been well recognized for over 30 years [4], and applies globally [5,6], in both civilian and military settings [7]. However, outcomes from severe hemorrhage remain poor, with mortality rates approaching 50\% for patients who require massive blood transfusion or who develop a significant coagulopathy $[8,9]$. Management of trauma hemorrhage depends on a

\footnotetext{
* Correspondence: Nicola.Curry@nhsbt.nhs.uk

${ }^{1} \mathrm{NHS}$ Blood and Transplant, Oxford Radcliffe Hospitals NHS Trust and

University of Oxford, Headley Way, Oxford, OX3 9BQ, UK

Full list of author information is available at the end of the article
}

multifactorial approach of timely surgical intervention, fluid resuscitation and blood transfusion therapy [10].

Advances have taken place in our understanding of the pathophysiology of trauma induced coagulopathy $[11,12]$, in the availability of rapid diagnostic modalities [13], and the introduction of hemostatic resuscitation strategies [14]. Conversely, evidence reviews have shown that some accepted therapies such as blood or plasma transfusion may be ineffective or associated with worse outcomes [15,16].

Existing reviews have focused on individual interventions, such as transfusion ratios [16-19], blood substitutes [20], or pharmaceutical agents [21,22]. Our objective was to conduct a systematic review of the wider trial literature for all randomized controlled trials (RCTs) relevant to the early management of trauma patients with bleeding. We specifically aimed to appraise

\section{() Biomed Central}

(c) 2011 Curry et al.; licensee BioMed Central Ltd. This is an open access article distributed under the terms of the Creative Commons Attribution License (http://creativecommons.org/licenses/by/2.0), which permits unrestricted use, distribution, and reproduction in any medium, provided the original work is properly cited. 
the methodology of the trials and to assess a broad range of outcomes focusing on bleeding and transfusion requirements, correction of coagulopathy and mortality.

\section{Materials and methods \\ Search strategy}

We followed a study specific protocol for this systematic review. All RCTs relating to early management of hemorrhage, transfusion or traumatic coagulopathy in severely injured patients of any age were considered for inclusion. No language restrictions were set. MeSH index and free text terms combined with RCT filters were used to search MEDLINE (1950 to July 2010), EMBASE (1980 to July 2010), and CENTRAL (The Cochrane Library Issue 7, 2010). We searched the ongoing trial registers: Current Controlled Trials, ClinicalTrials.gov and the World Health Organization International Clinical Trials Registry Platform (ICTRP). The National Health Service Blood and Transplant Systematic Review Initiative (NHSBT SRI) RCT Handsearch Database (1980 to July 2010) and the Cochrane Injuries Group Specialist Register were searched, and the reference lists of the identified RCTs and relevant narrative reviews were checked for additional trials. Papers not published in English were translated. Full details of the search are presented in Additional file 1.

\section{Selection criteria}

Citations and abstracts identified by the searches were screened for relevance by one reviewer. Full publications of accepted studies were assessed by two reviewers working independently against the inclusion/exclusion criteria. The criteria for inclusion of full reports were: at least $75 \%$ of the subjects were trauma patients with bleeding or hemorrhagic shock; interventions were applied within 24 hours of injury; the RCTs compared treatment and placebo or alternative treatments; outcomes reported included bleeding, blood loss, coagulopathy, or transfusion requirements; and allocation of the groups was by formal randomization or a quasi-random method. Data were recorded on mortality and morbidity including multi-organ failure (MOF), acute respiratory distress syndrome (ARDS) and infection. Trials assessing isolated traumatic brain injury or burns were excluded.

\section{Data abstraction and quality assessment}

Data were abstracted onto study specific forms by one reviewer and verified by a second reviewer. This included: country of origin, clinical setting, study population, trial structure, study quality, nature and duration of intervention and control groups, outcomes assessed and conclusions reported. Disagreements were resolved by consensus. Assessment of the methodological quality of the eligible RCTs was undertaken. We assessed the generation of random sequence, concealment of allocation, blinding of allocation and incomplete outcome data [23].

\section{Analysis}

We performed a descriptive analysis as it was not possible to undertake a meta-analysis due to the heterogeneity of the interventions. The RCTs were grouped into four clinical areas: blood and blood saving strategies; mechanical and surgical management; use of intravenous fluids for resuscitation; and pharmaceutical agents.

\section{Results}

The search strategy identified 11,856 citations. A total of 120 citations were relevant and reviewed at full text. After exclusions (Figure 1) [24], 35 completed RCTs were eligible for analysis (Additional file 2) [25-63]. Four trials are ongoing [64-67] (Table 1) and three have been terminated [68-70] (Table 2). Trials ranged in size from 32 to 20,211 participants and the majority $(n=23)$ were single centre studies. Thirty-four trials were of parallel group design and one a crossover trial [49]. Nine studies examined a pre-hospital intervention [32,34,41-44, 47-49], one study used an intervention in both pre-hospital and hospital settings [31] and the remaining interventions were administered in-hospital $[25,26,29,30,33$, 35-40,45,46,50-57,61-63].

The majority of trials $(n=31)$ recruited trauma patients exclusively, but four studies included non-trauma patients comprising between 4 and $25 \%$ of participants $[25,32,45,46]$, totalling 81 patients. All 35 studies included civilian patients only. Six trials only recruited participants with penetrating injuries $[29,34,35,41,48,57]$ and one only blunt injury [57]. The 22 studies that included both types of injury had a mean penetrating injury rate of $37 \%$ (range 1 to $89 \%$ ). Twenty-five studies provided data on injury severity scores (ISS) of participants. The mean ISS for studies reporting ISS was 24 , range 15 to 33 . The inclusion criteria for participants varied. Three studies used a systolic blood pressure (SBP) below $80 \mathrm{mmHg}[38,37,46], 15$ RCTs used $90 \mathrm{mmHg}[29,31,33,34,39-41,43,44,48,51$, $52,56,61,63]$ and 3 studies used $100 \mathrm{mmHg}[30,42,53]$. Only one RCT used base deficit as an inclusion criterion [61]. Seventeen studies provided data on the percentage of participants receiving blood transfusions (overall mean $74 \%$, range: 5 to $100 \%$ ) [25,26,31,33,35,36,38,39,42,46, 55-57,61,62]. Enrolled patients receiving massive transfusion (over 10 units of RBC in 24 hours) varied from 6 to $100 \%$ (mean 30\%) $[25,36,37,42,53,57,61]$.

Methodological quality is summarized in Additional file 3 and Figure 2[71]. Only 12 studies described adequate sequence generation methods. Allocation concealment was detailed in 23 studies and adequate in 13 . Twenty-one trials did not report blinding, 14 reported 


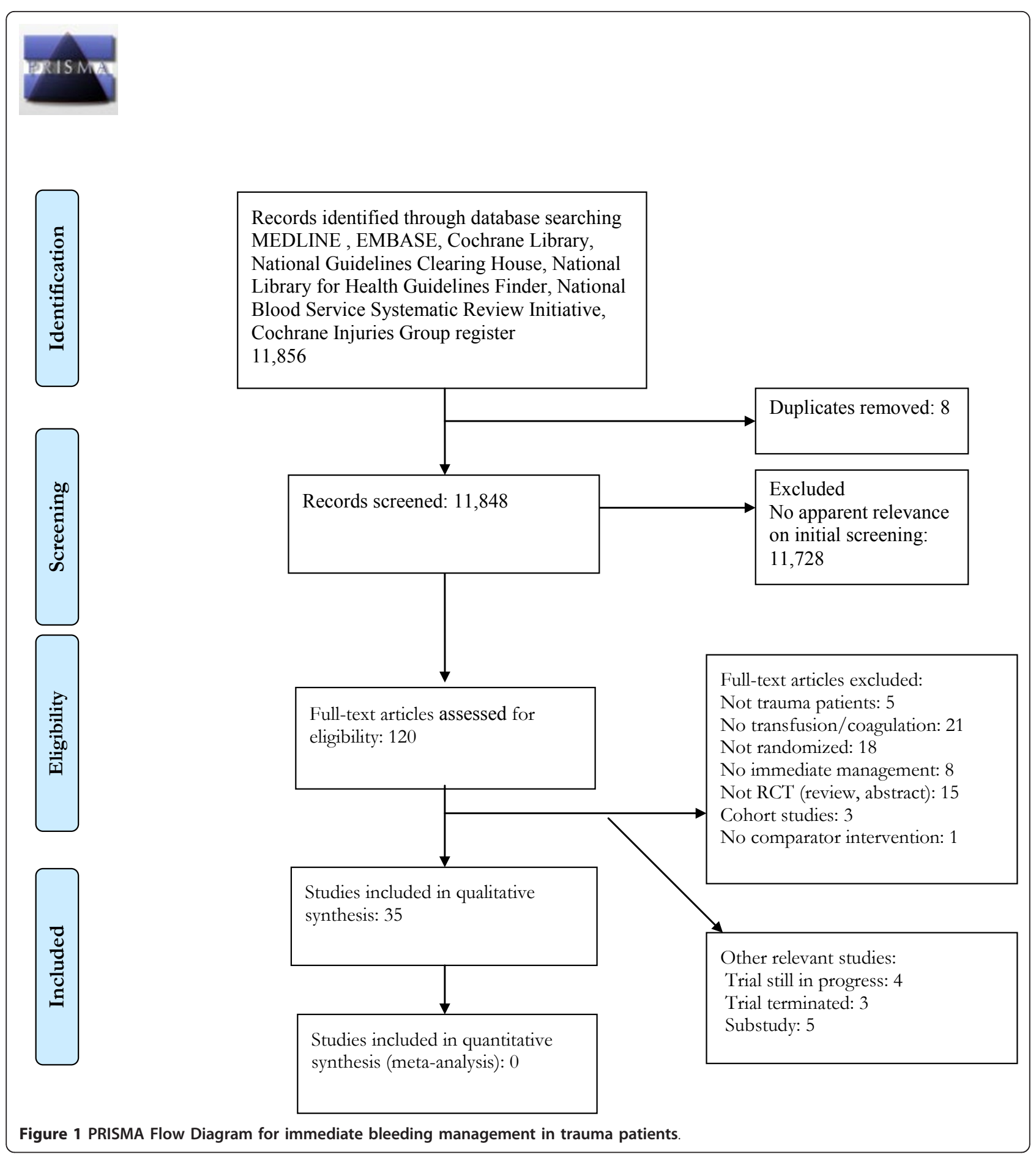

blinding of either participants or personnel and 4 of these also reported blinding of the outcome assessor. Most studies $(n=26)$ had no loss of patients, and five had less than $10 \%$ loss to follow-up. Only one study used good methodological practices in all areas examined [56]. There was no trend to improvement in methodological quality over time.
Blood and blood saving strategies (seven trials enrolling 1,374 participants)

Seven RCTs were identified which examined blood products $(n=2)$ or blood saving strategies $(n=5)$. Of the two RCTs that looked at blood product administration, one compared platelet therapy with fresh frozen plasma (FFP) for the prevention of microvascular bleeding [25]. 
Table 1 On-going studies

\begin{tabular}{|c|c|c|c|c|c|c|}
\hline On-going study & $\begin{array}{l}\text { Clinical group of trauma } \\
\text { patients }\end{array}$ & $\begin{array}{l}\text { Intervention } \\
\text { details }\end{array}$ & $\begin{array}{l}\text { Comparator } \\
\text { details }\end{array}$ & $\begin{array}{l}\text { Primary } \\
\text { endpoint }\end{array}$ & $\begin{array}{l}\text { Target } \\
\text { number to } \\
\text { be } \\
\text { recruited }\end{array}$ & $\begin{array}{l}\text { Expected } \\
\text { end date }\end{array}$ \\
\hline $\begin{array}{l}\text { CRISTAL: Colloids versus crystalloids } \\
\text { for resuscitation of critically ill } \\
\text { patients }\end{array}$ & $\begin{array}{l}\text { ITU patients, fluid } \\
\text { resuscitation }\end{array}$ & Colloids & Crystalloids & $\begin{array}{l}28 \text { day } \\
\text { mortality }\end{array}$ & 3,010 & $\begin{array}{l}\text { March } \\
2011\end{array}$ \\
\hline $\begin{array}{l}\text { High versus low MAP for trauma } \\
\text { patients undergoing surgery }\end{array}$ & $\begin{array}{l}\text { Adults, } \mathrm{SBP}<90 \mathrm{mmHg} \text {, } \\
\text { requiring laparotomy or } \\
\text { thoracotomy, }\end{array}$ & $\begin{array}{l}\text { Target minimum } \\
\text { mean arterial BP } \\
50 \mathrm{mmHg}\end{array}$ & $\begin{array}{l}\text { Target minimum } \\
\text { mean arterial BP } \\
65 \mathrm{mmHg}\end{array}$ & $\begin{array}{l}30 \text { day } \\
\text { survival }\end{array}$ & 271 & July 2011 \\
\hline $\begin{array}{l}\text { FIRST: Colloids versus crystalloids for } \\
\text { resuscitation of trauma patients }\end{array}$ & $\begin{array}{l}\text { Adults, requiring } \geq 3 \text { litres } \\
\text { of fluid }\end{array}$ & $\begin{array}{l}\text { HES 130/0.4 in } \\
\text { saline (Voluven) }\end{array}$ & $0.9 \%$ saline & $\begin{array}{l}\text { Fluid } \\
\text { volumes } \\
\text { Over first } 24 \\
\text { hours }\end{array}$ & 140 & $\begin{array}{l}\text { December } \\
2009\end{array}$ \\
\hline $\begin{array}{l}\text { Formula-driven vs. laboratory-guided } \\
\text { transfusion in bleeding trauma } \\
\text { patients: a feasibility study }\end{array}$ & $\begin{array}{l}\text { Adults, requiring four units } \\
\text { of RBC in two hours and } \\
\text { ongoing blood loss }\end{array}$ & $\begin{array}{l}\text { FFP:RBC:platelets } \\
\text { ratio of } 1: 1: 1- \\
\text { formula }\end{array}$ & Standard of care & $\begin{array}{l}\text { Protocol } \\
\text { compliance } \\
\text { at } 12 \text { hours }\end{array}$ & 70 & $\begin{array}{l}\text { October } \\
2011\end{array}$ \\
\hline
\end{tabular}

FFP, fresh frozen plasma; GCS, Glasgow coma score; ITU, intensive care unit; MAP, mean arterial pressure; RBC, red blood cell; SBP, systolic blood pressure.

The second compared leucodepleted versus standard blood products in terms of infection [26], micro-chimerism [27], and acute lung injury [28]. Five RCTs looked at methods of reducing allogeneic blood use. One assessed red blood cell (RBC) salvage in abdominal injury [29] and four trials evaluated a blood substitute, (PolyHeme, Northfield Laboratories Inc., Evanston, Illinois, USA $[30,31]$ or diaspirin cross-linked hemoglobin - DCLHb, Baxter Healthcare, Round Lake, Illinois, USA [32,33]).

Mortality rates were not affected by platelet administration [25], leucodepleted blood products [26], or cell salvage [29]. Only two of the four blood substitute RCTs reported mortality and neither identified a difference in outcome [31,33]. Three of the blood substitute studies reported morbidity outcomes (MOF, ARDS or infection) with no significant findings [31-33].

Transfusion requirements were reduced by cell salvage at 24 hours [29]. Three of the blood substitute studies also reported a significant reduction in $\mathrm{RBC}$ requirements $[30,31,33]$. The fourth study of DCLHb did not report transfusion use [32]. There was no difference in microvascular bleeding in the RCT comparing platelet and FFP transfusions [25].

Four trials reported coagulation outcomes $[25,29,31,32]$. Neither platelet transfusion, when compared to FFP [25], nor cell salvage [29] led to any significant improvement in coagulation. DCLHb did not affect activated partial thromboplastin time (APTT) [32], but patients receiving PolyHeme had significantly increased rates of prolonged prothrombin time (PT) and APTT, although an imbalance in these parameters was seen at the time of randomization [31].

\section{Mechanical and surgical management. (two trials enrolling 257 participants)}

Only two RCTs were identified. One study examined the use of Pneumatic Anti-Shock Garments (PASG) for traumatic injury [34] and a second investigated whether vascular control of renal vessels during surgery for kidney injury altered outcome [35].

Table 2 Terminated studies

\begin{tabular}{|c|c|c|c|c|c|}
\hline Study & $\begin{array}{l}\text { Clinical group of } \\
\text { trauma patients }\end{array}$ & Intervention details & $\begin{array}{l}\text { Comparator } \\
\text { details }\end{array}$ & $\begin{array}{l}\text { Primary } \\
\text { endpoint }\end{array}$ & Completion/Termination date \\
\hline $\begin{array}{l}\text { Warming techniques } \\
\text { for treatment of } \\
\text { hypothermia in } \\
\text { polytrauma }\end{array}$ & $\begin{array}{l}\text { Adults, polytrauma, } \\
\text { GCS }>9, \text { ISS }>16 \\
\text { and ASCOT score }= \\
2 \text { to } 50 \%\end{array}$ & $\begin{array}{l}\text { Endovascular catheter } \\
+ \text { forced air warming }\end{array}$ & $\begin{array}{l}\text { Forced air } \\
\text { warming }\end{array}$ & $\begin{array}{l}\text { Morbidity } \\
\text { during } \\
\text { length of } \\
\text { stay }\end{array}$ & $\begin{array}{l}\text { Suspended July 2010. Insufficient numbers } \\
\text { of patients recruited }\end{array}$ \\
\hline $\begin{array}{l}\text { Hypertonic fluids for } \\
\text { resuscitation of } \\
\text { hypovolemic shock }\end{array}$ & $\begin{array}{l}\text { Adults, prehospital } \\
\text { SBP } \leq 70 \text {, or } \\
\text { prehospital SBP } 71- \\
90 \text { and } \mathrm{HR} \geq 108\end{array}$ & $\begin{array}{l}\text { Arm A: } 7.5 \% \\
\text { hypertonic saline/6\% } \\
\text { Dextran-70 Arm B: } \\
7.5 \% \text { hypertonic saline } \\
\text { three arm trial }\end{array}$ & $\begin{array}{l}\text { Arm C: } 0.9 \% \\
\text { normal saline }\end{array}$ & $\begin{array}{l}\text { 28-day } \\
\text { survival }\end{array}$ & $\begin{array}{l}\text { Terminated August } 2009 \text { - no difference in } \\
28 \text {-day survival (futility). Analysis reported } \\
\text { earlier but not higher mortality with } \\
\text { hypertonic saline arms. }\end{array}$ \\
\hline $\begin{array}{l}\text { Low dose vasopressin } \\
\text { versus placebo in } \\
\text { Traumatic Shock } \\
\text { Resuscitation }\end{array}$ & $\begin{array}{l}\text { Adults, SBP }<90 \\
\mathrm{mmHg}\end{array}$ & $\begin{array}{l}\text { Bolus vasopressin } 4 \mathrm{U} \text {, } \\
\text { then continuous } \\
\text { infusion } 2.4 \mathrm{U} / \text { hour for } \\
\text { five hours }\end{array}$ & Normal saline & $\begin{array}{l}\text { To develop } \\
\text { new } \\
\text { resuscitation } \\
\text { regimens }\end{array}$ & Terminated April 2009 - poor accrual rate \\
\hline
\end{tabular}

ASCOT, a severity characterization of trauma score; rFVIIa, recombinant activated factor VII; SBP, systolic blood pressure. 


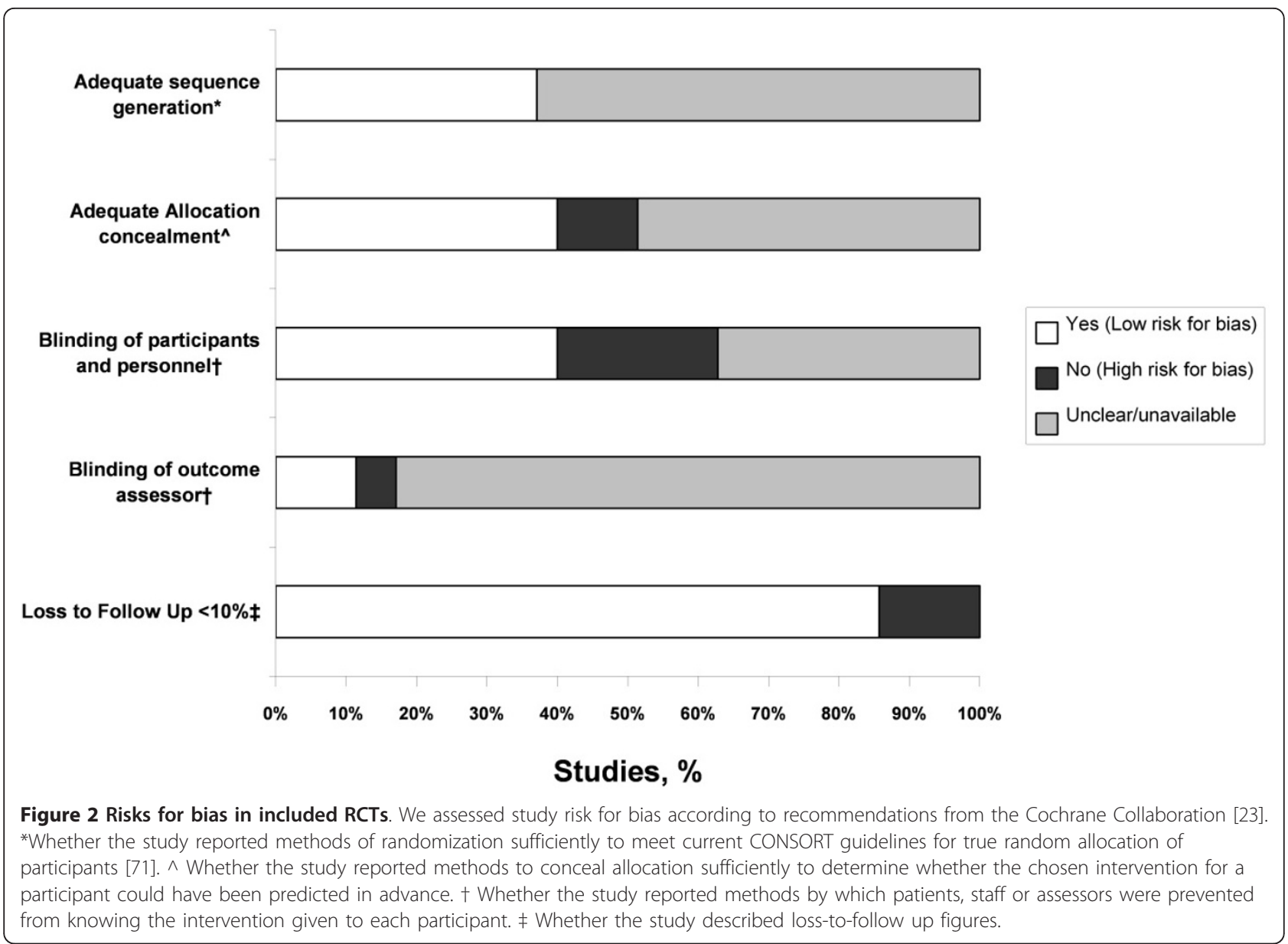

There was a trend to increased mortality in those patients treated with PASG [34]. Transfusion requirements were not altered by either intervention [34,35] and intra-operative blood loss was similarly unaffected during surgery for renal trauma [35]. Neither study reported coagulation results.

\section{Use of intravenous fluids for resuscitation (18 trials enrolling 3,394 participants)}

Twelve of 18 studies compared different resuscitation fluids: colloid vs. colloid $(n=1)$ [36]; colloid vs. crystalloid $(n=4)$ [37-40]; or crystalloid vs. hypertonic saline +/-dextran (HSD) $(n=7)$ [41-47]. The remaining six studies examined fluid administration strategies, including immediate vs. delayed (two RCTs) [48,49]; continuous arteriovenous rewarming (CAVR) (one RCT) [50]; and achievement of hemodynamic goals (three RCTs) [51-53]. The hemodynamic endpoint RCTs evaluated various interventions; the achievement of a certain systolic blood pressure (SBP) using a rapid infusion system [51]; a high or low SBP endpoint [52]; and the effect of increased hemodynamic monitoring against standard care [53].
Mortality was reduced at 24 hours and 30 days with HSD [46], but this was not reproduced in the six other HSD studies [41-45,47]. Delayed fluid administration led to a significant improvement in survival to hospital discharge in one of two studies on timing of fluid therapy [48]. The second study did not find any mortality difference [49]. No RCT of hemodynamic endpoints identified any significant mortality differences [51-53]. CAVR led to a significant reduction in mortality at 24 hours but no difference at hospital discharge [50].

Seven of 18 trials reported other clinical outcomes. Five evaluated the development of ARDS [37,48-51]. A significant increase was reported following albumin administration [37] and a trend was seen with CAVR [50]. Two studies reported MOF, both showing no difference between study arms [36,53]. Five RCTs reported infection data $[36,48-50,53]$ but only Plasma Protein Fraction (PPF) infusion showed a significant difference [36].

There was no difference in transfusion requirements in 10 of the 12 RCTs examining type of fluid administered [36-39,41-44,46,47]. A significant reduction in $\mathrm{RBC}$ use was reported at one hour with pentastarch [40] 
and throughout resuscitation with hypertonic solutions [45]. Transfusion requirements were not affected by timing of fluids $[48,49]$. Of the three RCTs examining hemodynamic endpoints only the rapid infuser showed a significant reduction in $\mathrm{RBC}$ transfusion and only in the first hour [51] CAVR did not affect blood product use [50].

Clotting parameters were reported in seven of these RCTs $[36,39,43,44,48,50,51]$. Three studies showed a difference: a higher APTT was seen on days 1 to 2 in patients receiving Hetastarch (HES) compared to PPF, but no difference in PT [36]; APTT was improved at 5 to 10 hours in patients receiving fluids via a rapid infusion system [51]; and there was a significantly prolonged PT and APTT in patients receiving immediate compared to delayed fluid therapy, but no significant difference after operative intervention [48].

\section{Pharmaceutical agents (eight trials enrolling 21,689 participants)}

Three of eight pharmaceutical trials reported effects of antifibrinolytics in trauma [54-56]. Aprotinin was compared to heparin [54] and to placebo [55] and tranexamic acid was compared to placebo [56]. Two RCTs (published as one paper [57]) reported the effects of recombinant factor VIIa (rFVIIa) in blunt and penetrating injury. Three post-hoc subgroup analyses [58-60] were published from these original data. A phase III RCT examining the efficacy of rFVIIa in the management of traumatic hemorrhage has been recently published [61]. Two RCTs looked at novel drugs examining the effects of a bactericidal protein (rBPI21) [62] and a monoclonal antibody (rhuMAb CD18) [63].

All pharmaceutical trials reported a mortality outcome. There was a significant reduction in death due to bleeding and all cause mortality in trauma patients receiving tranexamic acid [56]. The two small aprotinin RCTs did not identify a mortality benefit $[54,55]$. rFVIIa administration did not affect mortality $[57,58,61]$. A trend towards reduced mortality was reported at day 15 following administration of rBPI21 [62].

Five trials reported other clinical outcomes. Results from the phase II rFVIIa study reported no difference in MOF rates for blunt injury [57], and a trend to reduction of MOF in the penetrating [57], and the coagulopathic subgroups [58]. For those patients surviving more than 48 hours, there was a significant reduction in MOF rates in blunt trauma [59]. The phase III rFVIIa study reported a trend to reduction of MOF for blunt injury [61]. ARDS rates were significantly reduced in the intervention arms in three RCTs; rFVIIa in blunt injury [57] and the coagulopathic subgroup [58], aprotinin in pulmonary insufficiency [55] and rhuMAb CD18 [63]. A trend to reduction of ARDS was reported in the recent
rFVIIa RCT in blunt injury [61]. Rates of sepsis were unaffected by rFVIIa in either injury group in this same study [61].

Transfusion outcomes were reported in one of the three RCTs of antifibrinolytic agents [56]. Transfusion use was not altered over a 28-day period following administration of tranexamic acid. In contrast, rFVIIa led to a significant reduction in RBC $[57,61]$ and FFP [61] requirements in blunt injury and a trend to reduction of RBC [57] or total allogeneic transfusion [61] use in penetrating injury. In the coagulopathic subgroup a significant reduction in RBC and FFP use and a trend to a reduction in platelet use was reported at 48 hours [58]. Patients treated with rFVIIa and placebo received significantly greater numbers of massive transfusions if their post-study drug PT remained elevated at one hour [60]. Neither RCT examining novel drugs showed a difference in transfusion requirements $[62,63]$.

Little coagulation data were presented from the antifibrinolytic studies, and none from the novel drug RCTs. In the study where heparin was compared to aprotinin the heparin group was reported to have higher factor assay levels up to day 7 [54]. The RCTs examining rFVIIa in trauma originally did not report coagulation data [57]. In a subsequent report, rFVIIa reduced the mean PT and antithrombin and fibrinogen levels were significantly lower in patients with PT values $>18 \mathrm{~s}$ [60]. The phase III rFVIIa study reported no difference in disseminated intravascular coagulation (DIC) rates between rFVIIa and placebo [61].

\section{Discussion}

The 35 RCTs identified might be expected to provide a strong evidence base for a single clinical condition. However, the multifactorial nature of trauma hemorrhage, the multiplicity of interventions, issues with trial design, difficulties with the conduct of trauma trials and lack of a coordinated approach mean that only limited conclusions can be drawn. The largest sub group of included RCTs evaluated different strategies for using fluids during resuscitation, but did not consistently identify improvements in outcomes. The RCTs evaluating hemoglobin substitutes reported a reduction in RBC requirements but safety remains a concern [20]. Very few studies were identified evaluating the clinical effectiveness of RBC or blood component therapy. Only two studies were identified which evaluated surgical or mechanical interventions, which is surprising given the interest in damage control surgery [72] and angio-embolization [73]. Tranexamic acid was the only pharmaceutical agent that improved mortality [56].

Two studies reported bleeding endpoints using time taken to achieve hemorrhage control as their endpoint $[37,52]$, all other studies reported surrogate outcomes. 
Transfusion requirement was commonly used as a surrogate outcome for bleeding, but its use introduces issues with variations in transfusion practice, differences in product type and availability, and survivor bias [74]. Although transfusion for trauma hemorrhage is usually completed within a few hours of injury [75], a large proportion of the transfusion data was reported over a much longer timeframe. Differentiation between early and late transfusion use is an important distinction in understanding the effects of interventions for acute bleeding.

There was no demonstrable association between survival and transfusion requirements, despite evidence from observational studies [76,77]. None of the nine trials reporting a reduction in $\mathrm{RBC}$ use had an associated survival improvement [29-31,33,39,45,51,57,61]. Conversely, other studies reported survival benefits but did not observe differences in transfusion use $[46,48,56]$. No study used correction of coagulopathy as a defined endpoint. Newer methods of assessing hemostasis such as thromboelastography were not used and a definition of coagulopathy was variable and provided by a limited number of trials $[32,58,60]$.

Many of the included trials were poorly designed or conducted, underpowered or recruited small numbers of participants. Recruitment to trauma RCTs can be difficult, not least because of the challenges of enrolling incapacitated patients where informed consent is impossible, although some countries now have recognized processes for emergency consenting. Low patient numbers affect study power and increase the risk of bias, since baseline imbalances between patient groups is likely to occur even if randomization has been rigorous [78]. Only five studies were powered to provide mortality results, and it is likely that the improvement in mortality suggested by the sample size calculations (ranging between 6 and 35\%) was over optimistic in many studies [79]. In contrast the CRASH-2 study tested the hypothesis that tranexamic acid would provide a $2 \%$ survival benefit which projected a sample size of 20,000 participants [56].

There are limitations to this review. A quantitative analysis was not possible because of the heterogeneity between studies. For example, the inclusion criteria for patients varied widely, such as SBP values for shock. This increases the risk of missing low levels of benefit or harm, which were not large enough to be statistically relevant in any single RCT. The heterogeneity also highlights the importance of working towards uniformity in clinical trials. Attempts were made to identify all relevant RCTs including those in the non-English literature, but some studies may have been missed. Our literature search spanned 60 years, a time frame which has seen trauma care alter significantly. The included RCTs are all from civilian settings, and, therefore, RCT data do not exist to evaluate changes in military practice, although the recent changes in transfusion support for trauma patients have been driven by military data. There were no eligible RCTs examining, for example, the role of tourniquets and, therefore, this area has not been addressed in our review, although RCTs may not be indicated for every intervention.

\section{Conclusions}

The acute management of trauma hemorrhage has been evaluated in a large number of trials but these have not in the main produced results that have changed management or improved outcomes. This systematic review set out to examine RCTs, as the most robust form of study design and in so doing observational data have not been identified and appraised. However, it demonstrates that the difficulties associated with recruitment, design and conduct of trauma trials can be overcome to produce better quality RCTs. As our understanding of the pathophysiology of trauma hemorrhage grows, a coordinated strategy is required for this globally important condition.

\section{Key messages}

- A total of 35 RCTs were identified relating to the management of trauma haemorrhage, but due the multifactorial nature of hemorrhage, the multiplicity of the RCT interventions, issues with trial design and difficulties with the conduct of trauma trials, only limited conclusions could be drawn.

- The RCT literature did not demonstrate a correlation between reduction of transfusion requirement and improvement in the survival of their participants, even though the observational literature has reported such an association.

- Large, well-conducted studies with pragmatic endpoints are required to improve our understanding of the complex interplay between bleeding and coagulopathy, transfusion requirements and mortality. - The CRASH-2 study has confirmed that large, well-conducted trauma studies are achievable.

\section{Additional material}

Additional file 1: Search strategy. This file contains full documentation of the comprehensive search strategy completed for this systematic review.

Additional file 2: Included randomized controlled trials. This file contains a table listing all the included RCTs within this systematic review, including groups of patients examined, intervention and comparator arms and main clinical outcomes of each study.

Additional file 3: Quality assessment of included published randomized controlled trials. This file includes a table detailing the quality assessment of all included RCTs in this systematic review. It 
particularly focusses on sequence generation, allocation concealment, blinding and incomplete outcome data.

\section{Abbreviations}

APTT: activated partial thromboplastin time; ARDS: acute respiratory distress syndrome; CAVR: continuous arteriovenous rewarming; DCLHb: diaspirin cross linked hemoglobin; DIC: disseminated intravascular coagulation; FFP: fresh frozen plasma; HES: Hetastarch; HSD: hypertonic saline dextran; ICTRP. International Clinical Trials Registry Platform; ISS: injury severity score; MOF: multi organ failure; NHSBT SRI: National Health Service Blood and Transplant Systematic Review Initiative; PASG: pneumatic anti-shock garment; PPF: plasma protein fraction; PT: prothrombin time; RBC: red blood cell; rBPI21: bactericidal/permeability-increasing protein; RCT: randomized controlled trial; rFVIla: recombinant activated factor VIl; rhuMAbCD18: recombinant humanized monoclonal antibody against CD18; SBP: systolic blood pressure.

\section{Acknowledgements}

This research project was funded by the National Institute for Health Research Programme Grant for Applied Research (RP-PG-0407-10036).

\section{Author details}

${ }^{1}$ NHS Blood and Transplant, Oxford Radcliffe Hospitals NHS Trust and University of Oxford, Headley Way, Oxford, OX3 9BQ, UK. ${ }^{2}$ Systematic Review Initiative (SRI), NHS Blood and Transplant, John Radcliffe Hospital, Oxford, Headley Way, Oxford, OX3 9BQ, UK. 3 UK Cochrane Centre, 18-24 Middle Way, Summertown, Oxford, OX2 7LG, UK. ${ }^{4}$ Peninsula Technology Assessment Group (PenTAG), Peninsula College of Medicine and Dentistry, University of Exeter, EX2 4SG, UK. ${ }^{5}$ Trauma Sciences, Bart's and the London School of Medicine and Dentistry, Queen Mary University of London, London, E1 4NS, UK.

\section{Authors' contributions}

NC contributed to study design, acquisition of data, analysis and interpretation of data, drafted and revised the article. SH contributed to analysis and interpretation of data, and revision of the article. CD contributed to study design, acquisition of data, and revision of the article. $\mathrm{CH}$ and $\mathrm{KB}$ contributed to study conception and design, and revision of the article. SS contributed to study conception and design, acquisition of data, analysis and interpretation of data, and revision of the article.

\section{Competing interests}

The authors declare that they have no competing interests.

Received: 18 October 2010 Revised: 15 December 2010

Accepted: 9 March 2011 Published: 9 March 2011

\section{References}

1. World Health Organisation: Cause-specific mortality and morbidity (pp. 59-71). [http://www.who.int/whosis/whostat/EN_WHS10_Full.pdf].

2. Cothren CC, Moore EE, Hedegaard HB, Meng K: Epidemiology of urban trauma deaths: a comprehensive reassessment 10 years later. World J Surg 2007, 31:1507-1511.

3. Geeraedts LM Jr, Kaasjager HA, van Vugt AB, Frölke JP: Exsanguination in trauma: A review of diagnostics and treatment options. Injury 2009, 40:11-20.

4. Neuman TS, Bockman MA, Moody P, Dunford JV, Griffith LD, Guber SL, Guss DA, Baxt WG: An autopsy study of traumatic deaths; San Diego County, 1979. Am J Surg 1982, 144:722-727.

5. Sahdev P, Lacqua MJ, Singh B, Dogra TD: Road traffic fatalities in Delhi: causes, injury patterns, and incidence of preventable deaths. Accid Anal Prev 1994, 26:377-384.

6. Wright CS, McMurtry RY, Hoyle M, Pickard J: Preventable deaths in multiple trauma: review of deaths at Sunnybrook Medical Centre Trauma Unit. Can J Surg 1983, 26:20-23.

7. Holcomb JB, McMullin NR, Pearse L, Caruso J, Wade CE, Oetjen-Gerdes L, Champion HR, Lawnick M, Farr W, Rodriguez S, Butler FK: Causes of death in U.S. Special Operations Forces in the global war on terrorism: 20012004. Ann Surg 2007, 245:986-991.

8. Frith D, Goslings JC, Gaarder C, Maegele M, Cohen MJ, Allard S, Johansson Pl, Stanworth S, Thiemermann C, Brohi K: Definition and drivers of acute traumatic coagulopathy: clinical and experimental investigations. J Thromb Haemost 2010, 8:1919-1925.

9. Brohi K, Singh J, Heron M, Coats T: Acute traumatic coagulopathy. J Trauma 2003, 54:1127-1130

10. Rossaint $R$, Bouillon $B$, Cerny V , Coats T, Duranteau J, Fernández-Mondéjar E, Hunt BJ, Komadina R, Nardi G, Neugebauer E, Ozier Y, Riddez L, Schultz A, Stahel PF, Vincent JL, Spahn DR: Management of bleeding following major trauma: an updated European guideline. Crit Care 2010, 14:R52.

11. Hess JR, Brohi K, Dutton RP, Hauser CJ, Holcomb JB, Kluger Y, MackwayJones K, Parr MJ, Rizoli SB, Yukioka T, Hoyt DB, Bouillon B: The coagulopathy of trauma: a review of mechanisms. J Trauma 2008, 65:748-754.

12. Brohi K, Cohen MJ, Ganter MT, Matthay MA, Mackersie RC, Pittet JF: Acute traumatic coagulopathy: initiated by hypoperfusion: modulated through the protein C pathway? Ann Surg 2007, 245:812-818.

13. Johansson PI, Stissing T, Bochsen L, Ostrowski SR: Thromboelastography and thromboelastometry in assessing coagulopathy in trauma. Scand J Trauma Resusc Emerg Med 2009, 17:45.

14. Holcomb JB, Jenkins $D$, Rhee $P$, Johannigman J, Mahoney $P$, Mehta $S$, Cox ED, Gehrke MJ, Beilman GJ, Schreiber M, Flaherty SF, Grathwohl KW, Spinella PC, Perkins JG, Beekley AC, McMullin NR, Park MS, Gonzalez EA, Wade CE, Dubick MA, Schwab CW, Moore FA, Champion HR, Hoyt DB, Hess JR: Damage control resuscitation: directly addressing the early coagulopathy of trauma. J Trauma 2007, 62:307-310.

15. Stanworth SJ, Brunskill SJ, Hyde CJ, McClelland DB, Murphy MF: Is fresh frozen plasma clinically effective? A systematic review of randomized controlled trials. Br J Haematol 2004, 126:139-152.

16. Zehtabchi S, Nishijima DK: Impact of transfusion of fresh-frozen plasma and packed red blood cells in a 1:1 ratio on survival of emergency department patients with severe trauma. Acad Emerg Med 2009, 16:371-378.

17. Johansson PI, Stensballe J: Hemostatic resuscitation for massive bleeding: the paradigm of plasma and platelets - a review of the current literature. Transfusion 2010, 50:701-710.

18. Murad MH, Stubbs JR, Gandhi MJ, Wang AT, Paul A, Erwin PJ, Montori VM, Roback JD: The effect of plasma transfusion on morbidity and mortality: a systematic review and meta-analysis. Transfusion 2010, 50:1370-1383.

19. Phan $\mathrm{HH}$, Wisner $\mathrm{DH}$ : Should we increase the ratio of plasma/platelets to red blood cells in massive transfusion: what is the evidence? Vox Sang 2010, 98:395-402.

20. Chen J-Y, Scerbo M, Kramer G: A review of blood substitutes: examining the history, clinical trial results, and ethics of hemoglobin-based oxygen carriers. Clinics 2009, 64:803-813.

21. Lin Y, Stanworth S, Birchall J, Doree C, Hyde C: Recombinant factor Vlla for the prevention and treatment of bleeding in patients without haemophilia. Cochrane Database Syst Rev 2007, 2:CD005011.

22. Coats T, Roberts IG, Shakur H: Antifibrinolytic drugs for acute traumatic injury. Cochrane Database Syst Rev 2004, 4:CD004896.

23. Cochrane Handbook for Systematic Reviews of Interventions Version 5.0.2. [http://www.cochrane-handbook.org].

24. Moher D, Liberati A, Tetzlaff J, Altman DG, PRISMA Group: Preferred reporting items for systematic reviews and meta-analyses: The PRISMA statement. PLOS Med 2009, 6:e1000097.

25. Reed RL, Ciavarella D, Heimbach DM, Baron L, Pavlin E, Counts RB, Carrico CJ: Prophylactic platelet administration during massive transfusion. A prospective, randomized, double-blind clinical study. Ann Surg 1986, 203:40-48

26. Nathens AB, Nester TA, Rubenfeld GD, Nirula R, Gernsheimer TB: The effects of leukoreduced blood transfusion on infection risk following injury: a randomized controlled trial. Shock 2006, 26:342-347.

27. Utter GH, Nathens AB, Lee T-H, Reed WF, Owings JT, Nester TA, Busch MP Leukoreduction of blood transfusions does not diminish transfusionassociated microchimerism in trauma patients. Transfusion 2006, 46:1863-1869.

28. Watkins TR, Rubenfeld GD, Martin TR, Nester TA, Caldwell E, Billgren J, Ruzinski J, Nathens AB: Effects of leukoreduced blood on acute lung 
injury after trauma: A randomized controlled trial. Crit Care Med 2008, 36:1493-1499.

29. Bowley DM, Barker P, Boffard KD: Intraoperative blood salvage in penetrating abdominal trauma: a randomised, controlled trial. World J Surg 2006, 30:1074-1080.

30. Gould SA, Moore EE, Hoyt DB, Burch JM, Haenel JB, Garcia J, DeWoskin R, Moss GS: The first randomized trial of human polymerized haemoglobin as a blood substitute in acute trauma and emergent surgery. J Am Coll Surg 1998, 187:113-120.

31. Moore EE, Moore FA, Fabian TC, Bernard AC, Fulda GJ, Hoyt DB, Duane TM, Weireter L Jr, Gomez GA, Cipolle MD, Rodman GH Jr, Malangoni MA, Hides GA, Omert LA, Gould SA, PolyHeme Study Group: Human polymerized hemoglobin for the treatment of hemorrhagic shock when blood is unavailable: the USA multicenter trial. J Am Coll Surg 2009, 208:1-13.

32. Przybelski RJ, Daily EK, Micheels J, Sloan E, Mols P, Corne L, Koenigsberg MD, Bickell WH, Thompson DR, Harviel JD, Cohn SM: A safety assessment of diaspirin cross-linked hemoglobin (DCLHb) in the treatment of hemorrhagic, hypovolemic shock. Prehosp Disaster Med 1999, 14:251-264.

33. Kerner T, Ahlers O, Veit S, Riou B, Saunders M, Pison U, European DCLHb Trauma Study Group: DCL-Hb for trauma patients with severe hemorrhagic shock: the European "On-Scene" multicentre study. Intensive Care Med 2003, 29:378-385.

34. Bickell WH, Pepe P, Bailey ML, Wyatt CH, Mattox KL: Randomized trial of pneumatic antishock garments in the prehospital management of penetrating abdominal injuries. Ann Emerg Med 1987, 16:653-658.

35. Gonzalez RP, Falimirski M, Holevar M, Evankovich C: Surgical management of renal trauma: Is vascular control necessary? J Trauma 1999, 47:1039-1044.

36. Shatney CH, Deepika K, Militello PR, Majerus TC, Dawson RB: Efficacy of Hetastarch in the resuscitation of patients with multisystem trauma and shock. Arch Surg 1983, 118:804-809.

37. Lucas CE, Ledgerwood AM, Higgins RF, Weaver DW: Impaired pulmonary function after albumin resuscitation from shock. J Trauma 1980, 20:446-451.

38. Moss GS, Lowe RJ, Jilek J, Levine HD: Colloid or crystalloid in the resuscitation of hemorrhagic shock: A controlled clinical trial. Surgery 1981, 89:434-438.

39. Nagy KK, Davis J, Duda J, Fildes J, Roberts R, Barrett J: A comparison of Pentastarch and Lactated Ringer's solution in the resuscitation of patients with hemorrhagic shock. Circ Shock 1993, 40:289-294.

40. Younes RN, Yin KC, Amino CJ, Itinoshe M, Rocha e Silva M, Birolini D: Use of Pentastarch solution in the treatment of patients with hemorrhagic hypovolemia: Randomized phase II study in the emergency room. World J Surg 1998, 22:2-5.

41. Maningas PA, Mattox KL, Pepe P, Jones RL, Feliciano DV, Burch JM: Hypertonic saline-dextran solutions for the prehospital management of traumatic hypotension. Am J Surg 1989, 157:528-533.

42. Vassar MJ, Perry CA, Gannaway WL, Holcroft JW: 7.5\% Sodium Chloride/ Dextran for resuscitation of trauma patients undergoing helicopter transport. Arch Surg 1991, 126:1065-1072.

43. Vassar MJ, Perry CA, Holcroft JW: Prehospital resuscitation of hypotensive trauma patients with $7.5 \% \mathrm{NaCl}$ versus $7.5 \% \mathrm{NaCl}$ with added Dextran: a controlled trial. J Trauma 1993, 34:622-632, discussion 632-633.

44. Vassar MJ, Fischer RP, O'Brien PE, Bachulis BL, Chambers JA, Hoyt DB, Holcroft JW: A multicenter trial for resuscitation of injured patients with 7.5\% Sodium Chloride. The effect of added Dextran 70. Arch Surg 1993, 128:1003-1011, discussion 1011-1013.

45. Younes RN, Aun F, Accioly CQ, Casale LP, Szajnbok I, Birolini D: Hypertonic solutions in the treatment of hypovolemic shock: A prospective, randomized study in patients admitted to the emergency room. Surgery 1992, 111:380-385

46. Younes RN, Aun F, Ching CT, Goldenberg DC, Franco MH, Miura FK, Santos SS, Sequeiros IM, Rocha e Silva M, Fujimura I, Birolini D: Prognostic factors to predict outcome following the administration of hypertonic/hyperoncotic solution in hypovolemic patients. Shock 1997, 7:79-83.

47. Jousi M, Reitala J, Lund V, Katila A, Leppäniemi A: The role of pre-hospital blood gas analysis in trauma resuscitation. World J Emerg Surg 2010, 5:10.
48. Bickell WH, Wall MJ Jr, Pepe PE, Martin RR, Ginger VF, Allen MK, Mattox KL: Immediate versus delayed fluid resuscitation for hypotensive patients with penetrating torso injuries. NEJM 1994, 331:1105-1109.

49. Turner J, Nicholl J, Webber L, Cox H, Dixon S, Yates D: A randomised controlled trial of prehospital intravenous fluid replacement therapy in serious trauma. Health Technol Assess 2000, 4:1-57.

50. Gentilello LM, Jurkovich GJ, Stark MS, Hassantash SA, O'Keefe GE: Is hypothermia in the victim of major trauma protective or harmful? Ann Surg 1997, 226:439-449.

51. Dunham CM, Belzberg H, Lyles R, Weireter L, Skurdal D, Sullivan G: The rapid infusion system: a superior method for the resuscitation of hypovolemic trauma patients. Resuscitation 1991, 21:207-227.

52. Dutton RP, Mackenzie CF, Scalea TM: Hypotensive resuscitation during active hemorrhage: Impact on in-hospital mortality. J Trauma 2002, 52:1141-1146.

53. Velmahos GC, Demetriades D, Shoemaker WC, Chan LS, Tatevossian R, Wo CC, Vassiliu P, Cornwell EE, Murray JA, Roth B, Belzberg H, Asensio JA, Berne TV: Endpoints of resuscitation of critically injured patients: Normal or supranormal? A prospective randomized trial. Ann Surg 2000, 232:409-418.

54. Kolbow H, Barthels M, Oestern H-J, Sturm J, Wannske M, Schaps D: [Early changes of the coagulation system in multiple injuries and their modification with heparin and Trasylol.]. Chir Forum Exp Klin Forsch 1977, 119-123, Article in German.

55. Rosengarten DS, McMichan JC, Philipp E: The effect of prophylactic proteinase inhibitor therapy on post-traumatic pulmonary insufficiency and platelet counts. Adv Exp Med Biol 1979, 120B:349-360.

56. CRASH-2 trial collaborators, Shakur H, Roberts I, Bautista R, Caballero J, Coats T, Dewan Y, El-Sayed H, Gogichaishvili T, Gupta S, Herrera J, Hunt B, Iribhogbe P, Izurieta M, Khamis H, Komolafe E, Marrero MA, Mejía-Mantilla J, Miranda J, Morales C, Olaomi O, Olldashi F, Perel P, Peto R, Ramana PV, Ravi RR, Yutthakasemsunt S: Effects of tranexamic acid on death, vascular occlusive events, and blood transfusion in trauma patients with significant haemorrhage (CRASH-2): a randomised, placebo-controlled trial. Lancet 2010, 376:23-32.

57. Boffard KD, Riou B, Warren B, Choong PI, Rizoli S, Rossaint R, Axelsen M, Kluger Y, NovoSeven Trauma Study Group: Recombinant factor Vlla as adjunctive therapy for bleeding control in severely injured trauma patients; two parallel randomized, placebo-controlled, double-blind clinical trials. J Trauma 2005, 59:8-15, Discussion 15-18.

58. Rizoli SB, Boffard KD, Riou B, Warren B, lau P, Kluger $Y$, Rossaint $R$, Tillinger M, NovoSeven Trauma Study Group: Recombinant activated factor VII as an adjunctive therapy for bleeding control in severe trauma patients with coagulopathy: subgroup analysis from two randomized trials. Crit Care 2006, 10:R178.

59. Boffard KD, Choong PIT, Kluger Y, Riou B, Rizoli SB, Rossaint R, Warren B, NovoSeven Trauma Study Group: The treatment of bleeding is to stop the bleeding! Treatment of trauma-related haemorrhage. Transfusion 2009, 49:240S-247S.

60. McMullin NR, Wade CE, Holcomb JB, Nielsen TG, Rossaint R, Riou B, Rizoli SB, Kluger Y, Choong PI, Warren B, Tortella BJ, Boffard KD, NovoSeven Trauma Study Group: Prolonged prothrombin time after recombinant activated factor VII therapy in critically bleeding trauma patients is associated with adverse outcomes. J Trauma 2010, 69:60-69.

61. Hauser CJ, Boffard K, Dutton R, Bernard GR, Croce MA, Holcomb JB, Leppaniemi A, Parr M, Vincent JL, Tortella BJ, Dimsits J, Bouillon B, CONTROL Study Group: Results of the CONTROL Trial: Efficacy and safety of Recombinant Activated factor VII in the Management of Refactory Traumatic Hemorrhage. J Trauma 2010, 69:489-500.

62. Demetriades D, Smith JS, Jacobson LE, Moncure M, Minei J, Nelson BJ, Scannon PJ: Bactericidal/Permeability-increasing protein (rBPI21) in patients with hemorrhage due to trauma: Results of a multicenter phase II clinical trial. J Trauma 1999, 46:667-676.

63. Rhee P, Morris J, Durham R, Hauser C, Cipolle M, Wilson R, Luchette F, McSwain N, Miller R: Recombinant humanized monoclonal antibody against CD18 (rhuMAb CD18) in traumatic hemorrhagic shock: Results of a phase II clinical trial. J Trauma 2000, 49:611-620.

64. NCT00318942. Efficacy and safety of colloids versus crystalloids for fluid resuscitation in critically ill patients. (CRISTAL). [http://www.clinicaltrials. gov/ct2/show/NCT00318942?term=NCT00318942\&rank=1]. 
65. NCT00459160. A comparison of two target mean arterial pressures in the resuscitation of hypotensive trauma patients. [http://www. clinicaltrials.gov/ct2/show/NCT00459160?term=NCT00459160\&rank=1].

66. ISRCTN42061860. Comparison of crystalloid-blood resuscitation with crystalloid-colloid-blood resuscitation in severe trauma patients: a randomised double-blind trial (FIRST). [http://www.controlled-trials.com/ ISRCTN42061860].

67. NCT00945542. The Trauma-Formula-Driven versus Lab-Guided Study (TRFL Study). [http://www.clinicaltrials.gov/ct2/show/NCT00945542? term $=$ NCT00945542\&rank=1].

68. NCT00555126. Forced air versus endovascular warming in polytrauma patients. [http://www.clinicaltrials.gov/ct2/show/NCT00555126? term=NCT00555126\&rank=1].

69. NCT00316017. Hypertonic resuscitation following traumatic injury. [http://www.clinicaltrials.gov/ct2/show/NCT00316017? term $=$ NCT00316017\&rank=1].

70. NCT00420407. Low dose vasopressin in traumatic shock. [http://www clinicaltrials.gov/ct2/show/NCT00420407?term=NCT00420407\&rank=1].

71. Schulz KF, Altman DG, Moher D: CONSORT 2010 Statement: updated guidelines for reporting parallel group randomised trials. BMJ 2010, 340: c332.

72. Shapiro MB, Jenkins DH, Schwab CW, Rotondo MF: Damage control: collective review. J Trauma 2000, 49:969-978.

73. Durai $\mathrm{R}, \mathrm{Ng}$ PC: Role of angio-embolisation in trauma - review. Acta Chir Belg 2010, 110:169-177.

74. Stansbury L, Dutton R, Stein D, Bochicchio GV, Scalea TM, Hess JR Controversy in trauma resuscitation: do ratios of plasma to red blood cells matter? Transfus Med Rev 2009, 23:255-265.

75. Demetriades D, Murray J, Charalambides K, Alo K, Velmahos G, Rhee P Chan L: Trauma fatalities; time and location of hospital deaths. J Am Coll Surg 2004, 198:20-26.

76. Malone DL, Dunne J, Tracy JK, Putnam AT, Scalea TM, Napolitano LM: Blood transfusion, independent of shock severity, is associated with worse outcome in trauma. J Trauma 2003, 54:898-905, discussion 905-907.

77. Bochicchio GV, Napolitano L, Joshi M, Bochicchio K, Meyer W, Scalea TM: Outcome analysis of blood product transfusion in trauma patients: a prospective, risk-adjusted study. World J Surg 2008, 32:2185-2189.

78. Wilkinson KL, Brunskill SJ, Doree C, Hopewell S, Stanworth S, Murphy MF, Hyde C: The clinical effects of red blood cell transfusion: an overview of the randomized controlled trials evidence base. Transfus Med Rev 2011.

79. Aberegg SK, Richards DR, O'Brien JM: Delta inflation: a bias in the design of randomized controlled trials in critical care medicine. Crit Care 2010, 14:R77.

doi:10.1186/cc10096

Cite this article as: Curry et al:: The acute management of trauma

hemorrhage: a systematic review of randomized controlled trials. Critical Care 2011 15:R92.

\section{Submit your next manuscript to BioMed Central and take full advantage of:}

- Convenient online submission

- Thorough peer review

- No space constraints or color figure charges

- Immediate publication on acceptance

- Inclusion in PubMed, CAS, Scopus and Google Scholar

- Research which is freely available for redistribution

Submit your manuscript at www.biomedcentral.com/submit 